\title{
Comparative effects of microalgal species and food concentration on suspension feeding and energy budgets of the pearl oysters Pinctada margaritifera and P. maxima (Bivalvia: Pteriidae)
}

\author{
H. Yukihira ${ }^{1}$, D. W. Klumpp ${ }^{2, *}$, J. S. Lucas ${ }^{3}$ \\ ${ }^{1}$ Department of Zoology and Tropical Ecology, School of Biological Sciences, James Cook University, Townsville, \\ Queensland 4811, Australia \\ ${ }^{2}$ Australian Institute of Marine Science, PMB 3, Townsville MC, Queensland 4810, Australia \\ ${ }^{3}$ Department of Aquaculture, School of Biological Sciences, James Cook University, Townsville, Queensland 4811, Australia
}

\begin{abstract}
This study aimed to determine the influence of microalgal species and food concentration on various physiological parameters and Scope for Growth (SFG) in adults of 2 pearl oysters, Pinctada margaritifera and $P$. maxima. Clearance rate, pseudofaecal production rate, absorption efficiency, respiration rate and excretion rate were determined over a range of food concentrations using 2 microalgal diets, Tahitian Isochrysis sp. (T-Iso) and Dunaliella primolecta at $28^{\circ} \mathrm{C}$. Clearance, pseudofaecal production and respiration rates were significantly affected by microalgal diet. From these results, and because of the higher energy content of T-Iso, pearl oysters feeding on T-Iso had maximum values of SFG that were 1.5 to 2.1 times higher than when feeding on $D$. primolecta. Clearance rate and absorption efficiency were significantly related to food concentration as negative exponential relationships $(p<0.001)$. Generally, pseudofaecal production, respiration and excretion rates were significantly related to food concentration as positive linear relationships $(p<0.005)$. Optimal food concentrations for maximum SFG for $P$. margaritifera and $P$. maxima were 1 to $2 \mathrm{mg} \mathrm{l}^{-1}$ and 2 to $3 \mathrm{mg} \mathrm{l}^{-1}$, respectively. $P$. maxima was better adapted to a wider range of food concentrations. P. maxima maintained positive SFG up to $9 \mathrm{mg} \mathrm{l}^{-1}$ food concentration when feeding on T-Iso and up to $7 \mathrm{mg} \mathrm{l}^{-1}$ when feeding on $D$. primolecta, while equivalent values for $P$. margaritifera were $7 \mathrm{mg} \mathrm{l}^{-1}$ and $5 \mathrm{mg} \mathrm{l}^{-1}$, respectively. These results are in accordance with $P$. maxima occurring in a wider range of habitats than $P$. margaritifera, and experiencing greater concentration ranges of suspended particulate matter
\end{abstract}

KEY WORDS: Bivalve Pinctada maryaritifera Pinctada maxima Food Suspension feeding Scope for Growth Energy

\section{INTRODUCTION}

Food concentration and microalgal diet are major factors influencing the growth and reproduction of suspension feeding bivalves. The relationships between suspension feeding and energy budget versus food concentration and food quality have been well studied in temperate bivalves, but not generally in tropical

\footnotetext{
- Addressee for correspondence

E-mail: d.klumpp@aims.gov.au
}

bivalves (the exception is giant clams). These studies of temperate bivalves aimed to better understand their ecophysiology and trophic roles in aquatic ecosystems (Tenore \& Dunstan 1973a, b, Widdows et al. 1979, Navarro et al. 1992, Hawkins et al. 1996). Some also sought to determine optimum food conditions for aquaculture purposes (Tenore \& Dunstan 1973a, b, KirbySmith \& Barber 1974, Navarro \& Winter 1982, Beiras et al. 1993, 1994, Navarro et al. 1996). In particular, energy balances obtained for various microalgal diets and concentrations are of interest for bivalve aquaculture because pure cultures of unicellular microalgae 
are widely used as food for rearing larvae and spat. and for broodstock maturation. However, in spite of comparisons of nutritive values of microalgae (Finlay \& Uhlig 1981, Pillsbury 1985, Helm \& Laing 1987, Whyte 1987 ) and growth rates of bivalves (Walne 1970, Helm 1977. Ewart \& Epifanio 1981, Langdon \& Waldock 1981) on various diets, the way that different microalgal diets influence feeding (filtration, pseudofaeces production, ingestion and digestion) and energy balance has not been fully appreciated. Thus, studies of the influence of microalgal diet and concentration on feeding and energy balance of commercially important bivalve species can provide useful information for both ecology and aquaculture.

Pinctada margaritifera and $P$. maxima are economically important bivalves, as well as being typical suspension feeders occurring in tropical waters. They are among the largest species of pearl oysters (Bivalvia: Pteriidae) and are used extensively in cultured pearl production (Doumenge et al. 1991, Shirai 1994). They tend to occur in different habitats. P. margaritifera is found in greatest numbers in the oligotrophic waters of atoll lagoons; it tends to be excluded from turbid waters (Tranter 1959). On the other hand, P. maxima inhabits a variety of areas, from seagrass beds to deepwater 'reefs' on substrates varying from mud to sand and gravel (Kailola et al. 1993). Its inshore habitats may have considerable terrigenous sediment, and substantial nutrient inputs and productivity levels (Gervis $\&$ Sims 1992). The distribution of P. maxima suggests that it will experience a wide range of concentrations of suspended particulate matter (SPM). SPM may also be high in its inshore habitats, with SPM quality depending on meteorological and tidal conditions. The 2 oyster species inhabit such different waters that food particle concentration and food quality should be important factors for their ecology and energetics. The 2 species may correspondingly show different patterns of energy gain and expenditure over various food concentrations and types.

Scope for Growth (SFG, $\mathrm{J} \mathrm{h}^{-1}$ ) is a measure of the energy available to the animal for growth and reproduction (Warren \& Davis 1967, Bayne \& Newell 1983, Griffiths \& Griffiths 1987). Yukihira et al. (1998) demonstrated that in simulated oligotrophic conditions (0.5 $\mathrm{mg} \mathrm{l}^{-1}$ Tahitian Isochrysis sp.), Pinctada margaritifera and $P$. maxima both had high clearance rates (CR) and high values of SFG compared to most other bivalves, including bivalves feeding on higher food concentrations. It appears that both species are capable of growing and reproducing under conditions of low food supply. This is most notable for $P$. maxima because its habitats may have high levels of SPM. Thus, following on from these findings for a low concentration of one microalga (Yukihira et al. 1998), it is appropriate to examine the effects of microalgal species and food concentration on feeding and energy budgets of $P$. margaritifera and $P$. maxima.

Effects of various algal diets and concentrations on feeding rates (Hayashi 1983), larval growth (Nishimura 1980), and spat growth (Wada 1973, Okauchi 1990) have been examined for the Japanese pearl oyster Pinctada fucata martensil. However, there has not been a comprehensive study of the effects of food species and concentration on feeding and energy budgets of a Pinctada species. The first aim of the present study was therefore to compare the suspension feeding (clearance, pseudofaeces production and absorption rates) and energy budgets (absorbed, respired and excreted energy) of $P$. margaritifera and $P$. maxima feeding on 2 microalgae species over a range of food concentrations. The second was to consider whether the results on feeding and energy budgets are related to differences between habitats of these pearl oyster species. The energy budgets of the pearl oysters were summarised in the parameter Scope for Growth.

\section{MATERIALS AND METHODS}

The techniques used in this study were similar to those of Yukihira et al. (1998). All experiments were carried out at $28 \pm 0.5^{\circ} \mathrm{C}$

Pearl oysters. Large Pinctada maxima $(132$ to $237 \mathrm{~mm}$ shell height, $\mathrm{n}=30$ ) and $P$. margaritifera (121 to $180 \mathrm{~mm}$ shell height, $n=40$ ) were put into pocket nets (Gervis \& Sims 1992) kept at ca $1.5 \mathrm{~m}$ depth suspended from a pontoon at Cape Ferguson, Australian Institute of Marine Science, North Queensland $\left(19^{\circ} 15^{\prime} \mathrm{S}\right.$, $\left.147^{\circ} 05^{\prime} \mathrm{E}\right)$. They were acclimated to these conditions for at least $3 \mathrm{wk}$ before use in all experiments. Water temperature varied from 26.0 to $29.5^{\circ} \mathrm{C}$ over the study period. The shells of all oysters were thoroughly cleaned of epibiota during the acclimation period and were re-cleaned the day before use in experiments. After the completion of each experiment, shell height $(\mathrm{SH}, \mathrm{mm})$, which is the greatest distance from the umbo to the bottom of a finger or growth process. was recorded. Measurements of feeding, respiration, and excretion rates and food absorption efficiency were performed as described below on a sample size of 30 to 40 oysters.

Microalgae. Two unicellular microalgal species, Tahitian Isochrysis aff. galbana Green (T-Iso) and Dunaliella primolecta Butcher, were separately used as food suspensions. These algae were selected for their range of cell size ( 4 to $8 \mu \mathrm{m}$ ) and because they are used in mariculture, or resemble natural phytoplankton (T-Iso). The energy contents of the microalgae were determined using a Parr 1421 semi-micro oxygen 
bomb calorimeter (following Whyte 1987). Experiments were conducted over an algal concentration range between 0 (= no food) and $11 \mathrm{mg}$ dry wt $\mathrm{l}^{-1}$ using algal cells from cultures in their logarithmic growth phase.

Clearance rates. The volume of water each oyster cleared of particulate material $\left(\mathrm{CR}, 1 \mathrm{~h}^{-1}\right)$ was determined using a flow-through system in which $0.45 \mu \mathrm{m}$ filtered seawater containing a constant concentration of algal food was allowed to run through a set of 4 chambers. Three of these contained an oyster, while the remaining one acted as a control. From the flow rate $\left(F, l h^{-1}\right)$, and the concentrations of algae immediately surrounding each oyster $\left(\mathrm{C}_{0}\right)$, in the outflow of control chamber $\left(C_{1}\right)$ and in the outflow of each experimental chamber $\left(\mathrm{C}_{2}\right)$, clearance rates were calculated from the following equation (after Hildreth \& Crisp 1976):

$$
\mathrm{CR}\left(1 \mathrm{~h}^{-1}\right)=\mathrm{F}\left(\mathrm{C}_{1}-\mathrm{C}_{2}\right) / \mathrm{C}_{0}
$$

Two chamber volumes, 6 and 181 , were used to hold the oysters according to their size. A constant flow rate between 25 and $35 \mathrm{l} \mathrm{h}^{-1}$ was maintained during the experiment. Oysters were placed in the flow-through chambers and kept undisturbed. Measurements were commenced at least $1 \mathrm{~h}$ after they showed enough gape as evidence of feeding. Algal concentrations were measured at $1 \mathrm{~h}$ intervals (means of 5 counts) using a high-speed particle counter (Coulter Multisizer) with a $140 \mu \mathrm{m}$ orifice tube. The ration level of each oyster was expressed as a mean value of $\mathrm{C}_{0}$.

Pseudofaeces. Pseudofaeces is uningested material that is rejected from the labial palps. Both oyster species tended to produce mucus-like, fragile masses of pseudofaeces at the higher food concentrations. These were distinguished by their colour and texture from faeces, which were darker-coloured ribbons or pellets. Deposited pseudofaeces were carefully collected from each chamber during and on completion of experiments. Pseudofaecal production was quantified by filtering samples onto pre-rinsed-and-ashed GF/C filter papers, rinsing with distilled water, drying, and ashing at $450^{\circ} \mathrm{C}$ for $5 \mathrm{~h}$. Proportion of pseudofaeces to total food filtered (PF, \%) was then calculated.

Absorption efficiency. The percentage of food consumed that was then absorbed was determined by comparing the fraction of faeces lost on ashing with that of samples of food suspension treated in the same way. Absorption efficiency (abs.eff., \%) was then calculated according to the equation of Conover (1966):

$$
\text { abs.eff. }(\%)=100 \times(f-e) /(1-e) f
$$

where $f$ and $e$ are the fractions of food and faeces lost on ashing, respectively.

Collection of faeces from the chambers was carried out on completion of the measurements of CR and excretion rate (see below). Samples were filtered onto pre-rinsed-and-ashed GF/C filter papers, rinsed with distilled water, dried and ashed at $450^{\circ} \mathrm{C}$ for $5 \mathrm{~h}$. Food samples consisting of 2 l samples of water and algae were collected from the control chamber and treated in the same way.

Respiration rate. Respiration rates $\left(\mathrm{R}, \mathrm{ml} \mathrm{h}^{-1}\right)$ were determined in 4 sealed chambers using YSI dissolved oxygen electrodes (Model 55). Three sizes of chambers, 2, 5 and 13 l, were used to hold the oysters, according to size. Before the experiments, oysters were fed the appropriate food concentration for at least $2 \mathrm{~h}$ in a $100 \mathrm{l}$ tank with aeration. Then 3 oysters were placed individually into sealed chambers with $0.45 \mu \mathrm{m}$ filtered seawater and algal food at the appropriate concentration. The fourth chamber served as a control. Water in each chamber was thoroughly mixed by a magnetic stirrer. A mesh platform separated oyster from stirrer bar. Oxygen concentration in each chamber was monitored at 5 min intervals. Preliminary research revealed that both species took at most $15 \mathrm{~min}$ to stabilise in the conditions of the respirometer chamber. Since the clearance rates of the oysters were quite high compared to the chamber volumes, which meant that the animals would quickly deplete the food suspension in the chamber, recordings were restricted to the first 10 or 15 min after the initial equilibration period. R was determined after Bayne et al. (1985).

Excretion rate. The rate of ammonia excretion ( $\mathrm{E}$, mg $\mathrm{NH}_{4}-\mathrm{N} \mathrm{h}^{-1}$ ) was determined on the completion of CR measurements. Oysters were carefully transferred into another set of 4 chambers containing $0.45 \mu \mathrm{m}$-filtered seawater. Three of these contained an oyster, while the remaining chamber acted as a control. Oysters were kept undisturbed for 60 to $90 \mathrm{~min}$ according to the volume of water and the oyster's body size. Duplicate samples $(10 \mathrm{ml})$ were collected from each chamber and filtered through a $0.45 \mu \mathrm{m}$ Sartorius minisart filter and frozen until assaying. Analyses for ammonia content were conducted using the phenolhypochlorite method of Solorzano (1969).

Size standardisation of $\mathbf{C R}, \mathbf{R}$ and $\mathbf{E}$. The dry tissue weight of each experimental oyster was calculated from shell height ( $\mathrm{SH}$ ) using the $\mathrm{SH}$-tissue weight relationships determined in a previous study (Yukihira et al. 1998). CR, R and E were standardised to that of a specimen of $10 \mathrm{~g}$ dry tissue weight ( $\mathrm{wt}$ ) to allow comparisons according to the equation:

$$
\mathrm{Ys}=(\mathrm{Ws} / \mathrm{We})^{b} \cdot \mathrm{Ye} \quad(\text { Navarro et al. 1991) }
$$

where Ys = size-standardised physiological rate, Ws $=$ standard size (dry tissue weight) $=10 \mathrm{~g}$, We = dry tissue wt of animal, b = size-weight exponent, and $Y e=$ uncorrected physiological rate. Table 1 shows b values used for the standardisation of CR, R and $E$ of both species. 
Scope for growth. Absorbed energy $\left(A E, J^{-1}\right)$ was calculated as follows:

$\mathrm{AE}=\mathrm{CR}(1-\mathrm{PF})($ abs.eff. $)($ energy content of the algal food)

Relationships between AE and food concentration were expressed by polynomial regression curves. Respired energy (RE, $J \mathrm{~h}^{-1}$ ) and excreted energy ( $\mathrm{EE}, \mathrm{J} \mathrm{h}^{-1}$ ) were calculated after Bayne et al. (1985) Scope for Growth $\left(\mathrm{SFG}, \mathrm{J} \mathrm{h}^{-1}\right)$ was determined using the equation:

$$
\operatorname{SFG}\left(\mathrm{J} \mathrm{h}^{-1}\right)=\mathrm{AE}-(\mathrm{RE}+\mathrm{EE})
$$

Data analysis. When the regression analysis showed that $C R, P F, R$, abs.eff. and $E$ were correlated with increasing food concentration, differences in these parameters between oyster species and microalgal diet were examined using ANCOVA with food concentration as the covariate. Since $\mathrm{R}$ of Pinctada maxima was independent of ration level, the effect of microalgal diet was tested using 1-way ANOVA. Predicted mean values from regression equations and their $95 \%$ confidence limits $(95 \% \mathrm{CL})$ for $\mathrm{AE}$ and RE were used to assess differences in SFG values between the 2 microalgal diets and 2 oyster species.

\section{RESULTS}

\section{Microalgae}

T-Iso had a mean diameter of ca $4.5 \mu \mathrm{m}$ and contained $20.27 \mathrm{~J} \mathrm{mg}^{-1}$ dry wt. Dunaliella primolecta was larger (ca $7.0 \mu \mathrm{m}$ ) and contained less energy: $15.06 \mathrm{~J}$ $\mathrm{mg}^{-1}$ dry wt.

\section{Clearance rates}

Clearance rates $\left(\mathrm{CR}, \mathrm{l} \mathrm{h}^{-1}\right)$ of both oysters were significantly, negatively correlated with food concentration (Fig. 1). Relationships between $C R$ and food concentration ( $\mathrm{FC}, \mathrm{mg} \mathrm{l}^{-1}$ dry wt) were best described by exponential functions (Table 2). Slopes of the regressions of clearance rate on food concentration differed significantly between oyster species and between microalgal diets (Table 3). With increasing food concentration the CR of Pinctada margaritifera de-

Table 1. Pinctada margantifera and P. maxima. Size-rate exponents (b values) of clearance rate $\left(C R, I h^{-1}\right)$, respiration rate $\left(R, \mathrm{ml} \mathrm{O}_{2} \mathrm{~h}^{-1}\right)$ and excretion rate $\left(\mathrm{E}, \mathrm{mg} \mathrm{NH}_{4}-\mathrm{N} \mathrm{h}^{-8}\right.$ ) (from Yukihira et al. 1998)

\begin{tabular}{|lcccc|}
\hline Species & Weight $(\mathrm{g})$ & $\mathrm{CR}$ & $\mathrm{R}$ & $\mathrm{E}$ \\
\hline P. margarithera & $0.043-12.83$ & 0.613 & 0.439 & 0.642 \\
P. maxima & $0.044-20.39$ & 0.613 & 0.561 & 0.789 \\
\hline
\end{tabular}

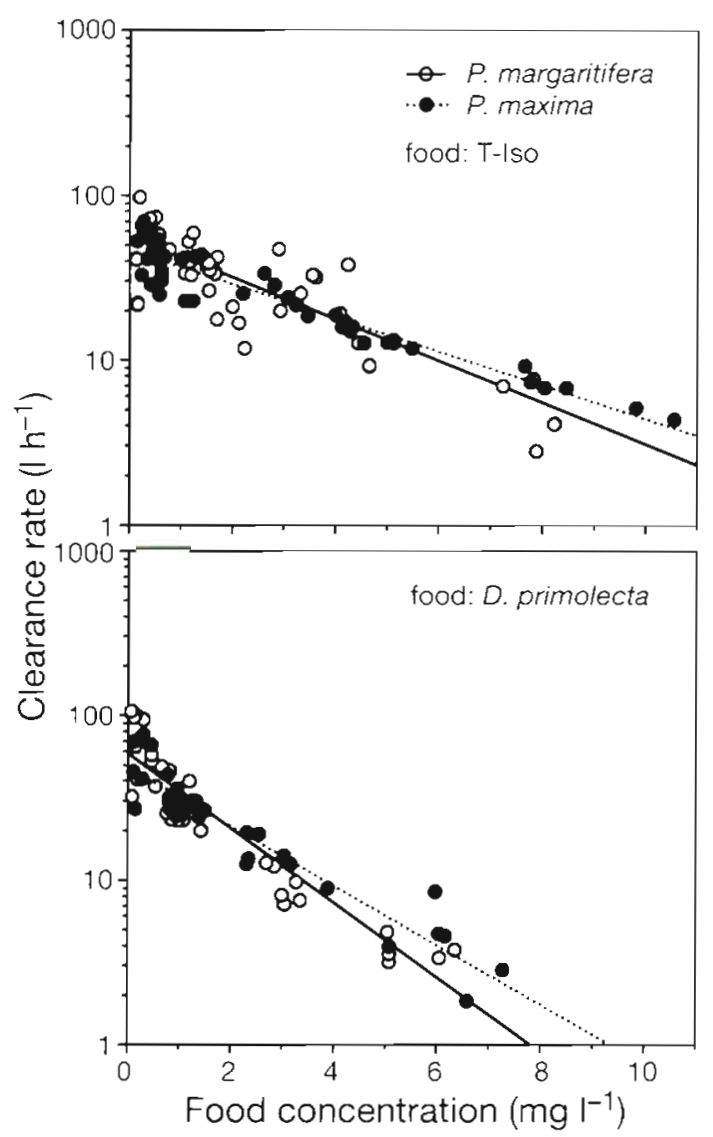

Fig. 1. Pinctada margaritifera and $P$, maxima. Clearance rate versus food concentration for oysters feeding on Tahitian Isochrysis sp. (T-Iso) (top) and Dunaliella primolecta (bottom). Each data point is the rate for a single oyster, standardised to $10 \mathrm{~g}$ dry tissue wt. Regression equations are in Table 2

creased significantly more than that of $P$. maxima (Fig. 1, Table 3a). CRs of oysters feeding on Dunaliella primolecta decreased significantly more with increasing FC than the CRs of oysters feeding on T-Iso (Fig. 1, Table 3c, d). Thus, the relationships between clearance rate and food concentration reflected both microalgal species and oyster species.

We observed that the shell gape of both oyster species tended to decrease at higher food concentrations, and the gills were never observed to extend beyond the shell margins. (Similarly, Palmer [1980] and Palmer \& Williams [1980] found that high clearance rates in scallops at low food concentrations were typically reflected in a wide shell gape.)

\section{Pseudofaecal production}

Relationships between pseudofaecal production (PF, $\%$ of total food filtered) and FC were described by 
Table 2. Pinctada margaritifera and $P$. maxima. Relationships between clearance $\left(1 \mathrm{~h}^{-1}\right)$, pseudofaecal production ( $\%$ of total food filtered), absorption etticiency $(\%)$, respiration $\left(\mathrm{ml} \mathrm{O}_{2} \mathrm{~h}^{-1}\right)$ and excretion rates ( $\left.\mathrm{mg} \mathrm{NH}_{4}-\mathrm{N} \mathrm{h}^{-1}\right)$, and food concentration ( $F \mathrm{C}, \mathrm{mg} \mathrm{m}^{-1}$ dry wt) of oysters feeding on Tahitian Isochrysis $\mathrm{sp}$. (T-Iso) or Dunaiiella primolecta

\begin{tabular}{|c|c|c|}
\hline \multirow{2}{*}{$\begin{array}{l}\text { Function } \\
\text { Microalgae species }\end{array}$} & \multicolumn{2}{|c|}{ Pearl oyster species } \\
\hline & P. margaritifera & P. maxima \\
\hline \multicolumn{3}{|l|}{ Clearance rate (CR) } \\
\hline T-Iso & $\begin{array}{l}C R=56.67 \times 10^{-0127 F C} \\
\left(r^{2}=0.74, n=50, p<0.001\right)\end{array}$ & $\begin{array}{l}C R=47.00 \times 10^{-0.102 F C} \\
\left(r^{2}=0.90, n=43, p<0.001\right)\end{array}$ \\
\hline D. primolecta & $\begin{array}{l}C R=58.31 \times 10^{-0.227 F C} \\
\left\{r^{2}=0.89, n=45, p<0.001\right\}\end{array}$ & $\begin{array}{l}C R=49.81 \times 10^{-0182 F} \\
\left(r^{2}=0.91, n=33, p<0.001\right)\end{array}$ \\
\hline \multicolumn{3}{|c|}{ Pseudofaecal production (PF) } \\
\hline T-Iso & $\begin{array}{l}\mathrm{PF}=8.52+4.39 \mathrm{FC} \\
\left(\mathrm{r}^{2}=026, \mathrm{n}=50, \mathrm{p}<0.001\right)\end{array}$ & $\begin{array}{l}P F=-1.80+3.78 F C \\
\left(r^{2}=0.68, n=43, p<0.001\right)\end{array}$ \\
\hline D. primolecta & $\begin{array}{l}\mathrm{PF}=-0.99+5.51 \mathrm{FC} \\
\left(\mathrm{r}^{2}=0.81, \mathrm{n}=45, \mathrm{p}<0.001\right.\end{array}$ & $\begin{array}{l}P F=-1.67+3.59 F C \\
\left(r^{2}=0.81, n=35, p<0.001\right)\end{array}$ \\
\hline \multicolumn{3}{|c|}{ Absorption efficiency (abs.efí.) } \\
\hline T-Iso & $\begin{array}{l}\text { abs.eff }=67.39 \times 10^{-0.108 F C} \\
\left(r^{2}=0.56, n=49, p<0.001\right)\end{array}$ & $\begin{array}{l}\text { abs eff. }=70.20 \times 10^{-00720 \mathrm{Fc}} \\
\left(\mathrm{r}^{2}=0.82, n=43, p<0.001\right)\end{array}$ \\
\hline D. primolecta & $\begin{array}{l}\text { abs eff }=55.29 \times 10^{-0} 0566 \mathrm{Fc} \\
\left(\mathrm{r}^{2}=0.55, \mathrm{n}=45, \mathrm{p}<0.001\right)\end{array}$ & $\begin{array}{l}\text { abs.eff. }=78.42 \times 10^{-0.0617 f C} \\
\left(\mathrm{r}^{2}=0.76, \mathrm{n}=32, \mathrm{p}<0.001\right)\end{array}$ \\
\hline \multicolumn{3}{|l|}{ Respiration (R) } \\
\hline T-Iso & $\begin{array}{l}\mathrm{R}=2.80+0.264 \mathrm{FC} \\
\left(\mathrm{r}^{2}=0.426, \mathrm{n}=24, \mathrm{p}<0.001\right)\end{array}$ & $\begin{array}{l}\mathrm{R}=3.76+0.0662 \mathrm{FC} \\
\left(\mathrm{r}^{2}=0.043, \mathrm{n}=28, \mathrm{~ns}\right)\end{array}$ \\
\hline D. primolecta & $\begin{array}{l}\mathrm{R}=1.81+0.238 \mathrm{FC} \\
\left(\mathrm{r}^{2}=0.621, \mathrm{n}=23, \mathrm{p}<0.001\right)\end{array}$ & $\begin{array}{l}\mathrm{R}=2.61+0.0610 \mathrm{FC} \\
\left(\mathrm{r}^{2}=0.055, \mathrm{n}=22, \mathrm{~ns}\right)\end{array}$ \\
\hline \multicolumn{3}{|l|}{ Excretion rate $(E)$} \\
\hline T-Iso & $\begin{array}{l}E=0.294+0.081 F C \\
\left(r^{2}=0.25, n=32, p<0.005\right)\end{array}$ & $\begin{array}{l}\mathrm{E}=0.374+0.110 \mathrm{FC} \\
\left(\mathrm{r}^{2}=0.40, \mathrm{n}=37, \mathrm{p}<0.001\right)\end{array}$ \\
\hline D. primolecta & $\begin{array}{l}E=0.225+0.096 F C \\
\left(r^{2}=0.57, n=29, p<0.001\right)\end{array}$ & $\begin{array}{l}E=0.346+0.127 F C \\
\left(r^{2}=0.50, n=35, p<0.001\right)\end{array}$ \\
\hline
\end{tabular}

Table 3. Summary of ANCOVA testing for similarity in slopes and intercepts of regression lines of clearance rate $\left(\mathrm{CR}, \mathrm{l} \mathrm{h}^{-1}\right)$, pseudofaecal production $(\mathrm{PF}, \%$ of filtered material), absorption efficiency (abs.eff., \%) and excretion rate (E, mg $\mathrm{NH}_{4}-\mathrm{N} \mathrm{h}^{-1}$ ) versus food concentration ( $\mathrm{mg} \mathrm{l}^{-1}$ dry wt) in pearl oyster Pinctada margaritifera and $P$. maxima, and food Tahitian Isochrysis sp. (T-Iso) and Dunaliella primolecta. When there was no significant difference in slope, then difference in intercept was tested. ns: not significant at $p<0.05 ; \quad p<0.05 ;{ }^{\prime} p<$ $0.01 ; \cdots p<0.001$

\begin{tabular}{|c|c|c|c|c|}
\hline & $C R$ & $\mathrm{PF}$ & abs.eff. & $E$ \\
\hline \multicolumn{5}{|c|}{ (a) Comparison between $P$. margaritifera and $P$. maxima feeding on T-Iso } \\
\hline Slopes & & $\mathrm{ns}$ & $\cdot$ & ns \\
\hline Intercepts & & $\cdots$ & ns & ns \\
\hline \multicolumn{5}{|c|}{ (b) Comparison between $P$. margaritifera and $P$. maxima feeding on $D$. primolecta } \\
\hline Slopes & $\cdot$ & $\cdots$ & ns & ns \\
\hline Intercepts & & & $\cdots$ & ns \\
\hline \multicolumn{5}{|c|}{ (c) Comparison between T-Iso and D. primolecta fed on by $P$. margantifera } \\
\hline Slopes & $\cdots$ & ns & . & ns \\
\hline Intercepts & & $\cdot \cdot$ & & ns \\
\hline \multicolumn{5}{|c|}{ (d) Comparison between T-Iso and D. primolecta fed on by P. maxima } \\
\hline Slopes & $\cdots$ & ns & ns & ns \\
\hline Intercepts & & ns & - & ns \\
\hline
\end{tabular}

linear functions (Table 2). PF, although showing considerable variability, increased significantly with increasing food concentration (Fig. 2). When the 2 oyster species were compared, slopes of the regressions of pseudofaeces production on food concentration were found to be significantly different for Dunaliella primolecta but not for T-Iso (Table 3a, b). However, the intercepts differed significantly between the oyster species when feeding on T-Iso (Table 3a). There was a significant difference between the intercepts of the regressions of pseudofaeces production on food concentration for the 2 microalgal diets for Pinctada margaritifera (Table $3 \mathrm{c}$ ), but no significant difference between the regressions of pseudofaeces production on food concentration for the microalgal diets for P. maxima.

Pinctada margaritifera produced relatively more pseudofaeces than $P$. maxima at comparable food concentrations. Only in $P$. margaritifera was there a difference between pseudofaecal production with different diets: T-Iso resulted in greater pseudofaecal production than Dunaliella primolecta at lower food concentration (Fig. 2).

\section{Absorption efficiency (abs.eff., \%)}

Relationships between abs.eff. and food concentration (FC) were best described by the exponential functions (Table 2). Abs.eff. declined significantly with increasing food concentration (Fig 3) Slopes or intercepts of the regressions of abs.eff. on food concentration varied significantly between oyster species and microalgal diets (Table 3). Pinctada maxima had higher abs.eff. than $P$. margaritifera regardless of diet. $P$. maxima had higher abs.eff. of Dunaliella primolecta compared to T-Iso at all food. concentrations. $P$. margaritifera had higher abs.eff, when feeding on $D$. primolecta compared with T-Iso, except at food concentrations below about $2 \mathrm{mg} \mathrm{l}^{-1}$. 


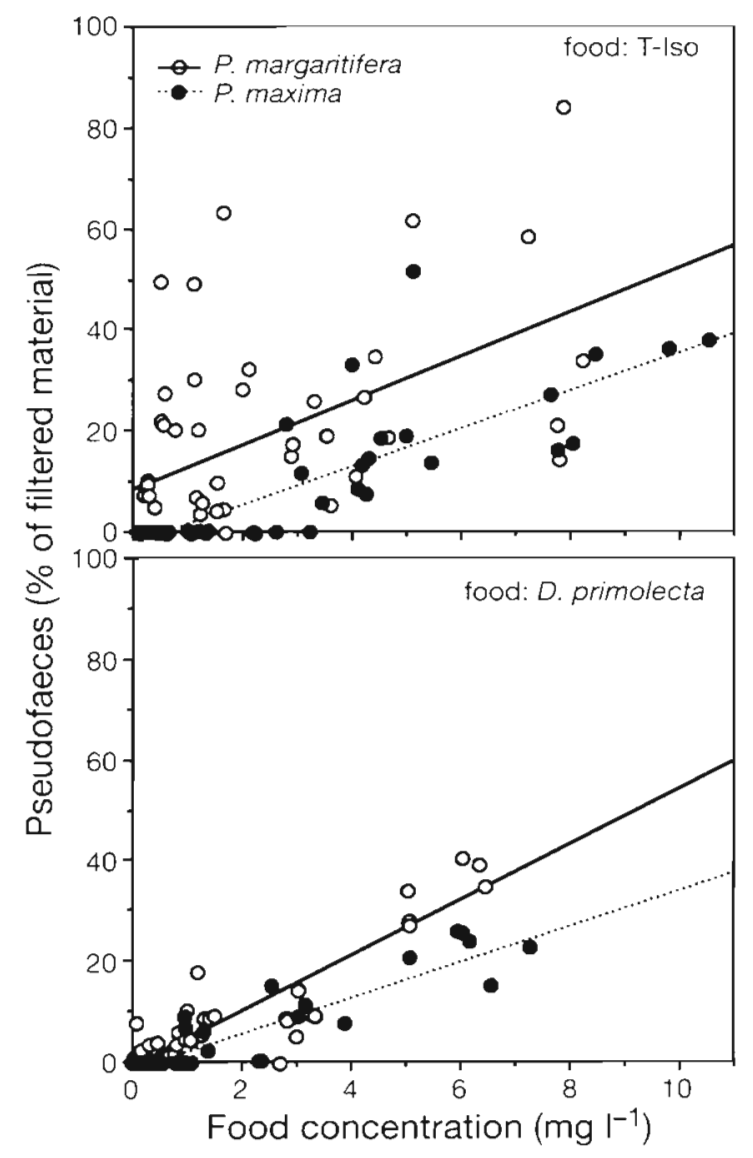

Fig. 2. Pinctada margaritifera and P. maxima. Pseudofaecal production ( $\%$ of total food filtered) versus food concentration for oysters feeding on Tahitian Isochrysis sp. (T-Iso) (top) and Dunaliella primolecta (bottom). Each data point is the rate for a single oyster, standardised to $10 \mathrm{~g}$ dry tissue wt. Regression equations are in Table 2

\section{Absorbed energy (AE)}

Relationships between AE and FC were best expressed by fourth-power polynomial regressions (Fig. 4).

Pinctada margaritifera (T-Iso)

$$
\begin{aligned}
\mathrm{AE} & =32.2+589.6 \mathrm{FC} \\
& +(-253.2) \mathrm{FC}^{2}+37.3 \mathrm{FC}^{3}+(-1.85) \mathrm{FC}^{4} \\
& \left(\mathrm{r}^{2}=0.82, \mathrm{n}=49, \mathrm{p}<0.001\right)
\end{aligned}
$$

P. margaritifera (Dunaliella primolecta)

$$
\begin{aligned}
\mathrm{AE} & =38.6+364.0 \mathrm{FC} \\
& +(-20.43) \mathrm{FC}^{2}+39.0 \mathrm{FC}^{3}+(-2.49) \mathrm{FC}^{4} \\
& \left(\mathrm{r}^{2}=0.76, \mathrm{n}=45, \mathrm{p}<0.001\right)
\end{aligned}
$$

P. maxima (T-Iso)

$$
\begin{aligned}
\mathrm{AE} & =97.8+403.6 \mathrm{FC}+(-121.0) \mathrm{FC}^{2} \\
& +12.5 \mathrm{FC}^{3}+(-0.45) \mathrm{FC}^{4} \\
& \left(\mathrm{r}^{2}=0.81, \mathrm{n}=43, \mathrm{p}<0.001\right)
\end{aligned}
$$

P. maxima (D. primolecta)

$$
\begin{aligned}
\mathrm{AE} & =88.9+322.2 \mathrm{FC} \\
& +(-125.0) \mathrm{FC}^{2}+16.16 \mathrm{FC}^{3}+(-0.70) \mathrm{FC}^{4} \\
& \left(\mathrm{r}^{2}=0.77, \mathrm{n}=33, \mathrm{p}<0.001\right)
\end{aligned}
$$

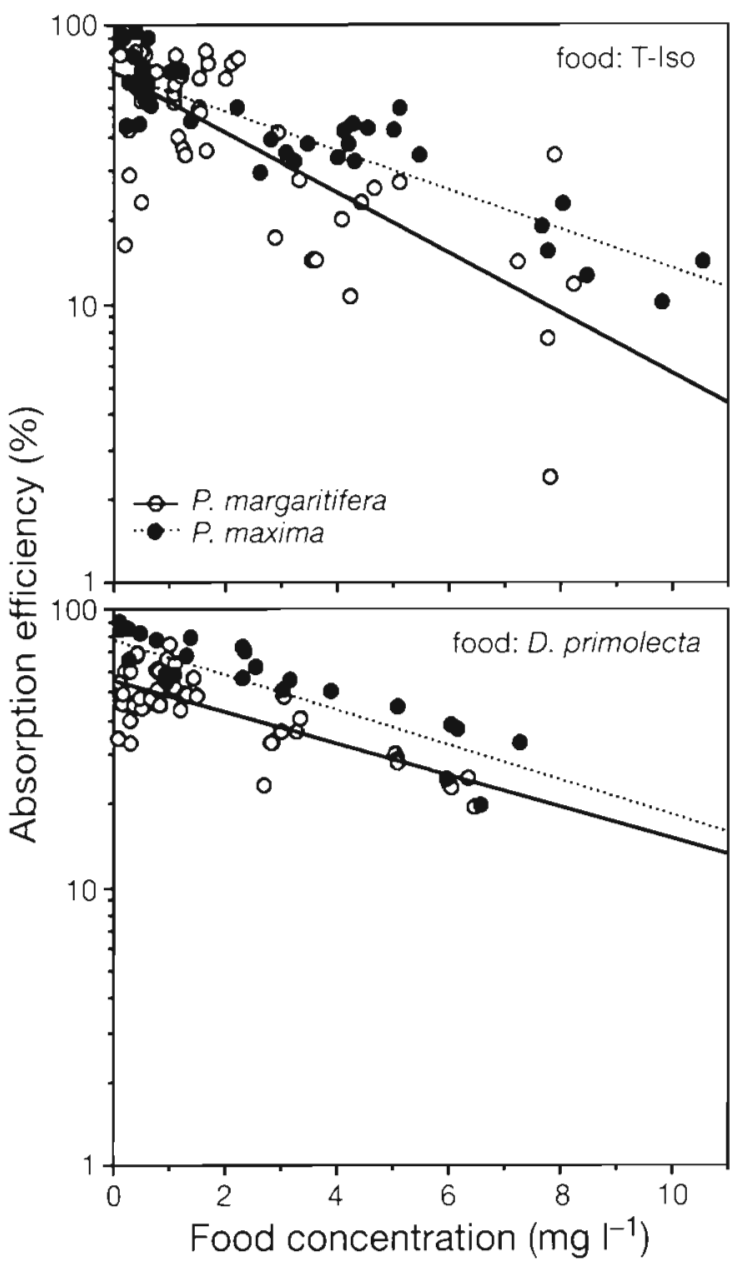

Fig. 3. Pinctada margaritifera and P. maxima. Absorption efficiency versus lood concentration for oysters feeding on Tahitian Isochrysıs sp. (T-Iso) (top) and Dunaliella primolecta (bottom). Each data point is the rate for a single oyster, standardised to $10 \mathrm{~g}$ dry tissue $w t$. Regression equations are in Table 2

Predicted mean values of $\mathrm{AE}$ and $95 \%$ confidence limits (95\% CL) corresponding to 1 to $10 \mathrm{mg} \mathrm{FC}^{-1}$ are shown in Table 4 Both pearl oysters feeding on T-Iso and Dunaliella primolecta displayed maximum values of $\mathrm{AE}$ within the range 1 to $3 \mathrm{mg} \mathrm{l}^{-1}$. The $95 \% \mathrm{CL}$ values show significant effects of food species concentration on AE of both pearl oysters. These effects were: (1) at food concentrations of 0.5 to $4.5 \mathrm{mg} \mathrm{I}^{-1}$ (Pinctada margaritifera) and 0.5 to $6.0 \mathrm{mg} \mathrm{l}^{-1}$ (P. maxima), pearl oysters feeding on T-Iso had higher AE values than those feeding on D. primolecta, and (2) P. maxima had higher AE at 2.5 to $6.0 \mathrm{mg} \mathrm{l}^{-1}$ (T-Iso) and 1 to $4.5 \mathrm{mg} \mathrm{l}^{-1}$ (D. primolecta) than P. margaritifera. Except for these food concentration ranges, there were no significant differences in $\mathrm{AE}$ values between oyster species or food species. 


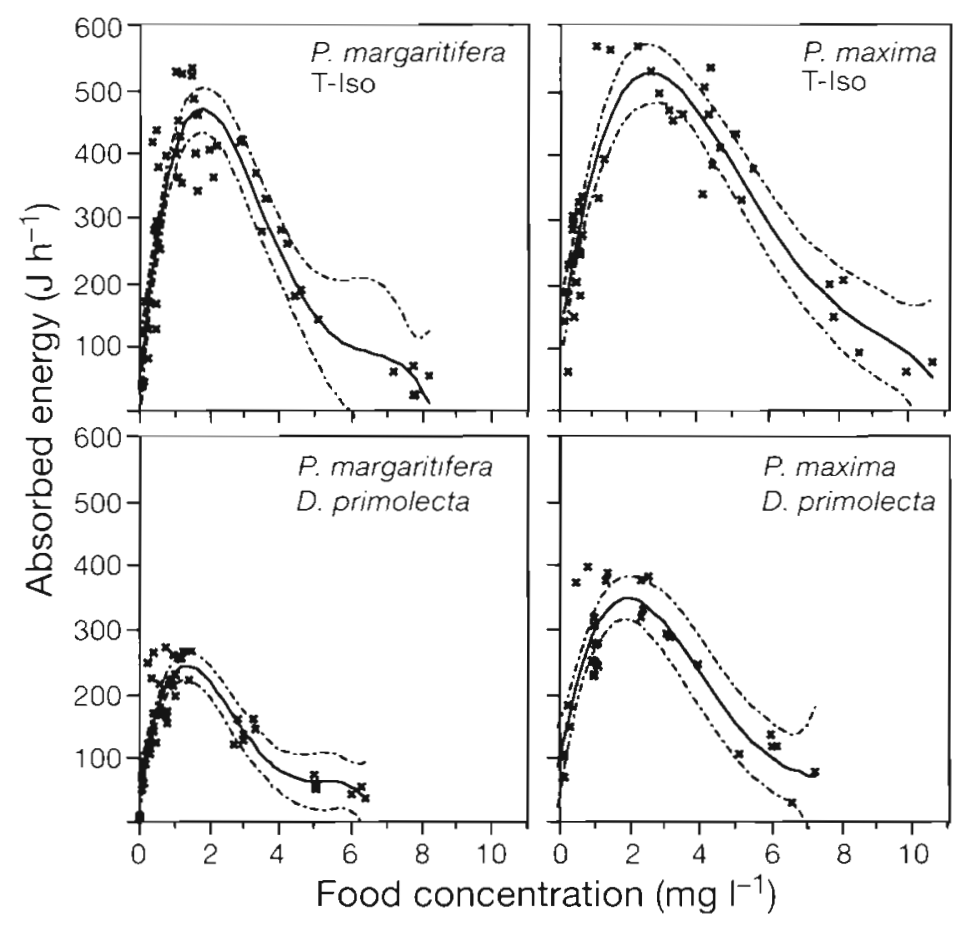

Fig. 4. Pinctada margaritifera and P. maxima. Relationships (regression curves and $95 \%$ confidence curves) between absorbed energy and food concentration for oysters feeding on Tahitian Isochrysis sp. (T-Iso) (top) and Dunaliella primolecta (bottom). Each data point is the rate for a single oyster, standardised to $10 \mathrm{~g}$ dry tissue wt. Regression equations are in Table 2

\section{Respiration}

There were linear relationships between respiration $\left(\mathrm{R}, \mathrm{ml} \mathrm{O}_{2} \mathrm{~h}^{-1}\right.$ ) and $\mathrm{FC}$ (Table 2). Respiration rate of Pinctada margaritifera increased significantly with increasing food concentration (Fig. 5, Table 5), but respiration rate of $P$. maxima was not significantly affected. Therefore, the mean $\mathrm{R}$ values for $P$. maxima were compared between the microalgal diets. P. maxima had significantly higher $\mathrm{R}$ when feeding on $\mathrm{T}$-Iso than on Dunaliella primolecta (Table 5, ANOVA, p < 0.01 ). These mean values of $R$ were used to calculate $\mathrm{RE}\left(\mathrm{J} \mathrm{h}^{-1}\right)$ and $95 \%$ CL values for P. maxima in Table 4.

Slopes of regression lines of $\mathrm{R}$ versus $\mathrm{FC}$ for Pinctada margaritifera were not significantly different for the 2 diets, but intercepts were significantly different (ANCOVA, $p<0.01$ ). Therefore relationships between $\mathrm{R}$ and $\mathrm{FC}$ for $P$. margaritifera were re-expressed as follows:

$$
\begin{aligned}
& \text { T-Iso } \\
& \mathrm{R}=2.80( \pm 0.496)+0.247 \mathrm{FC}, \\
& \text { Dunaliella primolecta } \\
& \mathrm{R}=1.81( \pm 0.406)+0.247 \mathrm{FC},
\end{aligned}
$$

where figures in parenthesis are $95 \%$ confidence limits $(95 \% \mathrm{CL})$. These regressions were used to calculate
RE and $95 \%$ CL of predicted mean RE for the comparison between microalgal diets.

To compare RE and $95 \% \mathrm{CL}$ between the oyster species feeding on the same food, the following regressions for Pinctada margaritifera were used:

T-Iso

$\mathrm{R}=2.80( \pm 0.496)+0.264( \pm 0.136) \mathrm{FC}$

Dunaliella primolecta

$\mathrm{R}=1.81( \pm 0.406)+0.238( \pm 0.084) \mathrm{FC}$

Calculated respired energy (RE, $\mathrm{J} \mathrm{h}^{-1}$ ) and $95 \%$ CL are shown in Table 4.

\section{Excretion}

Relationships between excretion rate ( $E, m g h^{-1}$ ) and food concentration were expressed by linear functions (Table 2). $E$ varied considerably, but increased significantly with increasing food concentration (Fig. 6). However, neither slopes nor intercepts of the regressions of $E$ on FC varied significantly between oyster species nor between microalgal diet (Table 3). Therefore, all data were pooled and a common regression was determined:

$$
\begin{gathered}
E=0.306+0.110 F C \\
\left(r^{2}=0.42, n=133, p<0.001\right)
\end{gathered}
$$

Excreted energy (EE, $\mathrm{J} \mathrm{h}^{-1}$ ) was calculated using this equation (Table 4 ).

\section{Scope for Growth}

Scope for Growth (SFG) values for Pinctada margaritifera and P. maxima feeding on T-Iso and Dunaliella primolecta were determined from calculated AE, RE and EE values (Table 4). Considering 95\% CL for $\mathrm{AE}$ and RE, $P$. maxima feeding on T-Iso and $D$. primolecta had distinctly higher SFG than $P$. margaritifera throughout ration levels 3 to $6 \mathrm{mg} \mathrm{l}^{-1}$ T-Iso and 2 to $4 \mathrm{mg}$ $\mathrm{I}^{-1}$ D. primolecta, respectively. P. margaritifera and $P$. maxima feeding on T-Iso had higher SFG than when feeding on $D$. primolecta over food concentration ranges 1 to $4 \mathrm{mg} \mathrm{l}^{-1}$ and 2 to $6 \mathrm{mg} \mathrm{l}^{-1}$, respectively. $P$. margaritifera and $P$. maxima feeding on $\mathrm{T}$-Iso had 2.1 times $\left(387 / 183 \mathrm{~J} \mathrm{~h}^{-1}\right)$ and 1.5 times $\left(423 / 280 \mathrm{~J} \mathrm{~h}^{-1}\right)$ higher maximum SFG values, respectively, than those feeding on D. primolecta. The highest SFGs of $P$. margaritifera and $P$. maxima feeding on the 2 diets were at approximately the following food concentrations: 


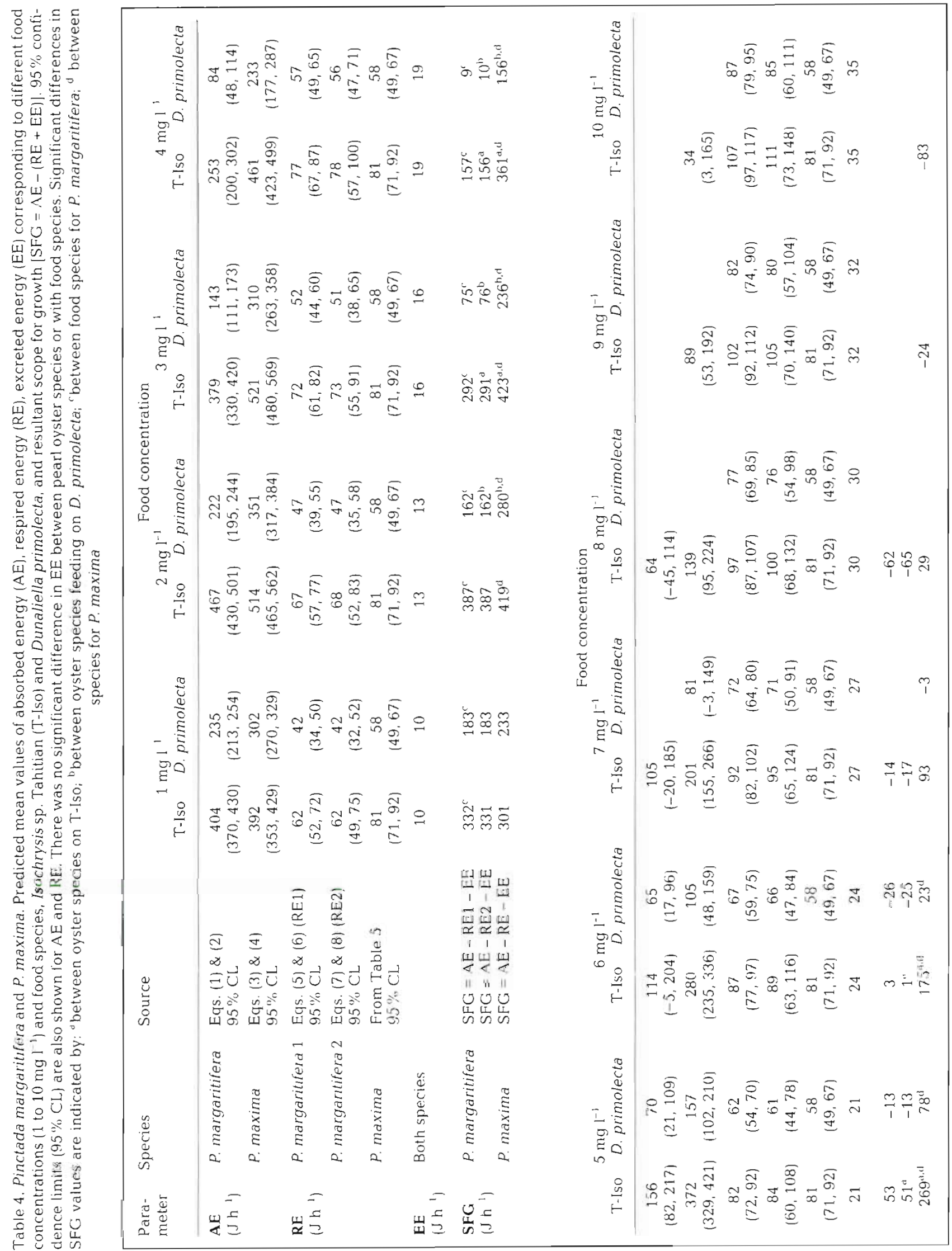




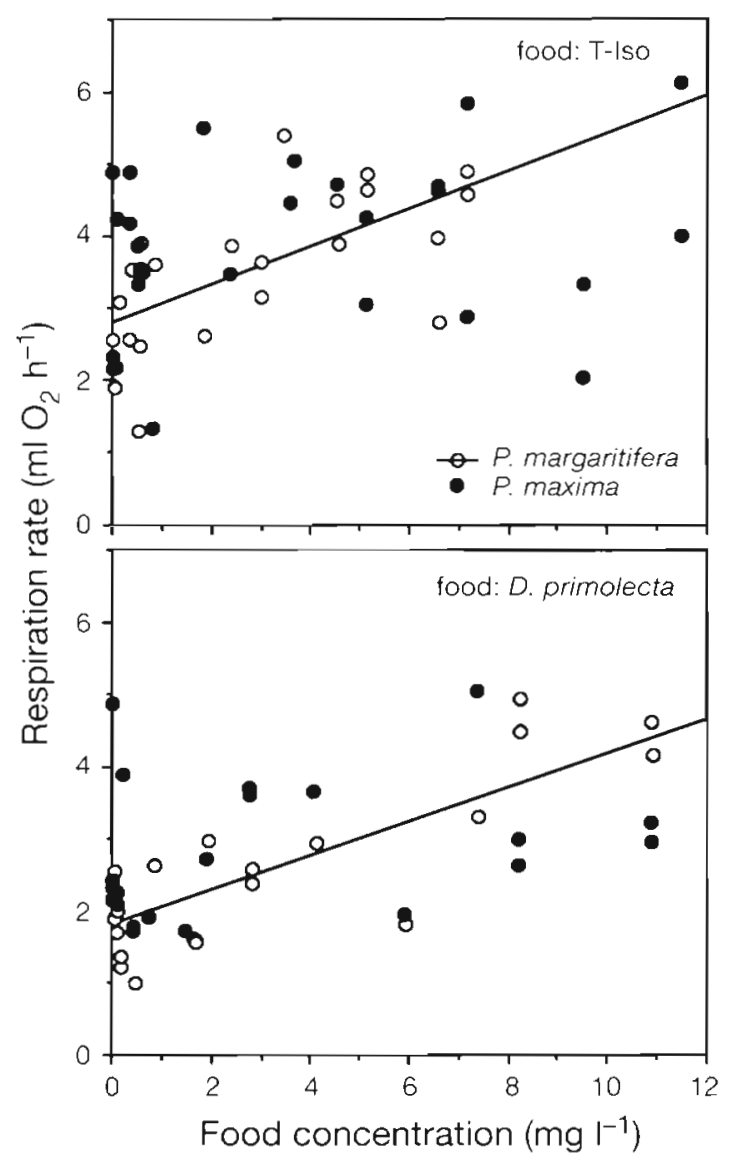

Fig. 5. Pinctada margaritifera and P. maxima. Respiration rate versus food concentration for oysters feeding on Tahitian Isochrysis sp. (T-Iso) (top) and Dunaliella primolecta (bottom). Each data point is the rate for a single oyster, standardised to $10 \mathrm{~g}$ dry tissue wt. Regression equations are in Table 2

P. margaritifera: $2 \mathrm{mg} \mathrm{l}^{-1}$ (T-Iso), $1 \mathrm{mg} \mathrm{l}^{-1}$ (D. primolecta) P. maxima: $\quad 3 \mathrm{mg} \mathrm{l}^{-1}$ (T-Iso), $2 \mathrm{mg} \mathrm{l}^{-1}$ (D. primolecta)

Above these peaks, SFG declined to below zero with increasing food ration level. The approximate upper threshold concentrations beyond which SFG values became negative were

P. margaritifera: $7 \mathrm{mg} \mathrm{l}^{-1}$ (T-Iso) and $5 \mathrm{mg} \mathrm{l}^{-1}$ (D. primolecta) P. maxima: $\quad 9 \mathrm{mg} \mathrm{l}^{-1}$ (T-Iso) and $7 \mathrm{mg} \mathrm{l}^{-1}$ (D. primolecta)

Table 5. Pinctada maxima. Mean respiration rates $\left(\mathrm{R}, \mathrm{ml} \mathrm{O}_{2}\right.$ $\mathrm{h}^{-1}$ ) and $95 \%$ confidence limits (CL) of oysters consuming various concentrations of Tahitian Isochrysis $\mathrm{sp}$. ( $\mathrm{T}-\mathrm{I}$ so) and Dunaliella primolecta. Food species has a significant effect on $\mathrm{R}$ (ANOVA, $\mathrm{p}<0.01$ )

\begin{tabular}{|lccc|}
\hline Food species & $\begin{array}{c}\text { Food concentration } \\
\left(\mathrm{mg} \mathrm{l^{-1 }}\right)\end{array}$ & $\mathrm{n}$ & $\mathrm{R}(\mathrm{CL})$ \\
\hline T-lso & $0-11.4$ & 28 & $4.00( \pm 0.513)$ \\
D. primolecta & $0-10.9$ & 22 & $2.86( \pm 0.458)$ \\
\hline
\end{tabular}

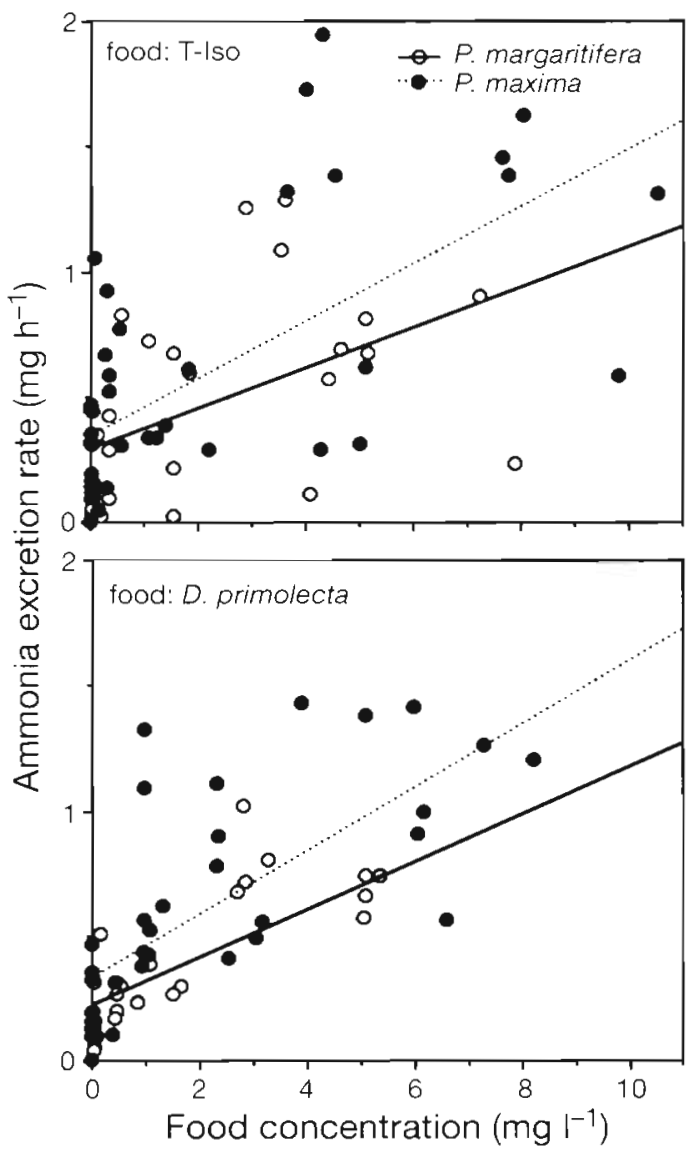

Fig. 6. Pinctada margaritifera and P. maxima. Excretion rate versus food concentration for oysters feeding on Tahitian Isochrysis sp. (T-Iso) (top) and Dunaliella primolecta (bottom). Each data point is the rate for a single oyster, standardised to $10 \mathrm{~g}$ dry tissue wt. Regression equations are in Table 2

Thus, Pinctada maxima maintained positive SFG over a wider range of food concentration than $P$. margaritifera.

\section{DISCUSSION}

\section{Effects of food concentration on energetics}

At high algal concentrations, suspension-feeding bivalves generally decrease clearance rates (Winter 1978 , Griffiths 1980) and absorption efficiency (Van Weel 1961, Thompson \& Bayne 1972, Griffiths \& King 1979, Griffiths 1980, Bayne et al. 1989, van Erkom Schurink \& Griffiths 1992), and increase pseudofaeces production (Foster-Smith 1975, Bayne \& Worrall 1980). This study of 2 tropical pearl oysters demonstrated similar trends (Figs. 1, 2 \& 3). Consequently, their absorbed energy (AE) was also strongly affected by increasing food concentration (Fig. 4). Both Pinctada margaritifera and $P$. maxima controlled the total amount of material in- 
gested in varying food environments by a combination of altering their clearance rates and the amount of material rejected in pseudofaeces. This agrees with observations for the sub-tropical pearl oyster Pinctada imbricata (Ward \& MacDonald 1996).

Pinctada margaritifera and $P$. maxima have distinctly different patterns of feeding and energy budgets. Yukihira et al. (1998) demonstrated that $P$. maxima had higher absorption efficiency (abs.eff.) than P. margaritifera at low food concentration $\left(0.5 \mathrm{mg} \mathrm{l}^{-1} \mathrm{~T}\right.$-Iso). There was no difference in clearance rate (CR) at this food level. The present study found that, at higher food concentrations, $P$. maxima had significantly higher abs.eff. and $C R$ than $P$. margaritifera, regardless of algal diet (Figs. $1 \& 3$, Table 3a, b). Due to this and the lower pseudofaecal wastage of potential food particles in $P$. maxima, this species had higher SFG at food concentrations of 3 to $6 \mathrm{mg} \mathrm{l}^{-1}$ (T-Iso) and 2 to $4 \mathrm{mg} \mathrm{l}^{-1}$ (D. primolecta) (Table 4). Thus, it would appear that $P$. maxima is better adapted to maximise energy gain at higher food concentrations compared with P. margaritifera.

Winter (1978) showed that increases in food concentration promote growth rates of bivalves only up to an optimum food concentration beyond which growth rates decline. In terms of maximisation of growth potentiality, optimal concentrations for $P$. margaritifera and $P$. maxima are 1 to $2 \mathrm{mg} \mathrm{l}^{-1}$ T-Iso (ca 10000 to 20000 cells $\mathrm{ml}^{-1}$ ) and 2 to $3 \mathrm{mg} \mathrm{l}^{-1}$ T-Iso (ca 20000 to 30000 cells $\mathrm{ml}^{-1}$ ), respectively, as indicated by measured SFG (Table 4). These ration levels are in the range of algal concentrations generating the highest SFG or growth rates recorded for other suspensionfeeding bivalves (Table 6).

\section{Eifects of food species on energetics}

The 2 microalgae species used in this study, T-Iso and Dunaliella primolecta, significantly influenced the $C R$, abs.eff. and respiration rate of both pearl oyster species (Table 3 ), and the pseudofaeces production of
Pinctada margaritifera. D. primolecta was not as good a food for pearl oysters as T-Iso at any ration level and the disparity increased at higher ration levels (Table 4 ). These effects of the microalgal species on the pearl oysters' feeding and metabolism were similar to other studies that demonstrated effects of diet on feeding in bivalves. Tenore \& Dunstan (1973b), for example, demonstrated that clearance rate of Crassostrea virginica was influenced by different microalgal diets and especially depressed by high concentrations of Dunaliella tertiolecta (cf. Fig 1), while Le Pennec \& Rangel (1985) reported that ingestion and digestion of $D$. primolecta by Pecten maximus were low and Isochrysis galbana was among the best algal diets.

Particle retention efficiency is about $100 \%$ in determinations of $C R$ for bivalves filtering particles greater than ca $4 \mu \mathrm{m}$ diameter (Bayne et al. 1985). This has been confirmed for Pinctada margaritifera and $P$. maxima (Yukihira et al. 1998). Since average diameters of T-Iso and Dunaliella primolecta are ca $4.5 \mu \mathrm{m}$ and $7.0 \mu \mathrm{m}$, respectively, the size difference is unlikely to influence filtration by the pearl oysters. There may be other factors affecting feeding upon different types of food, e.g. chemical stimulants on the surface of food particles. Dwivedy (1973) reported the presence of chemoreceptors, sensitive to different tastes, on the labial palps of the American oyster Crassostrea virginica, and Newell \& Jordan (1983) inferred chemoselection of particles by $C$. virginica. Energy used in digesting and absorbing energy from ingested food may be important (Thompson \& Bayne 1972, Bayne \& Scullard 1977).

The effects of food species on CR, abs.eff. and $R$ resulted in substantial differences in SFG between pearl oysters feeding on the 2 microalgal diets. T-Iso contains 1.3 times more energy than Dunaliella primolecta (20.3 and $15.1 \mathrm{~J} \mathrm{mg}^{-1}$, respectively), but oysters feeding on T-Iso had 1.5 to 2.1 times higher maximum SFG values than those feeding on $D$. primolecta (Table 4). This was in spite of higher respired energy (RE) for oysters feeding on T-Iso. (The higher oxygen

Table 6. Food levels used for highest Scope for Growth or highest recorded growth rates for filter-feeding bivalves

\begin{tabular}{|c|c|c|c|}
\hline Species & Food level & Food species & Source \\
\hline Pinctada margaritifera & $1-2 \mathrm{mgl}^{-1}$, ca $10000-20000$ cells ml $\mathrm{ml}^{-1}$ & Tahitian Isochrysis sp. & This study \\
\hline Pinctada maxima & $2-3 \mathrm{mg} \mathrm{l}^{-1}$, ca $20000-30000$ cells $\mathrm{ml}^{-1}$ & Tahitian Isochrysis sp. & This study \\
\hline Argopecten irradians & 6000 cells $\mathrm{ml}^{-1}$ & Tahitian Isochrysis sp. & Cahalan et al. (1.989) \\
\hline Aulacomya ater & ca $3 \mathrm{mg} \mathrm{l}^{-1}$ & Dunaliella primolecta & Griffiths \& King (1979) \\
\hline Choromytilus meridionalis & ca $2 \mathrm{mg} \mathrm{l}^{-1}$ & Dunaliella primolecta & Griffiths (1980) \\
\hline Mytilus chilensis & ca 15000 cells ml $]^{-1}$ & Dunaliella marina & Navarro \& Winter (1982) \\
\hline Mytilus edulis & ca 12000 cells ml $\mathrm{m}^{-1}$ & Tetraselmis suecica & Thompson \& Bayne (1974) \\
\hline Ostrea edulis (juveniles) & $200000 \mathrm{cells} \mathrm{m \textrm {m } ^ { - 1 }}$ & Isochrysis galbana & Beiras et al. (1994) \\
\hline Vencrupis pullastra (juveniles) & 300000 cells $\mathrm{ml}^{-1}$ & Isochrysis galbana & Beiras et al (1993) \\
\hline
\end{tabular}


consumption in pearl oysters feeding on T-Iso at all food concentrations [Table 5] may be due to higher mechanical and physiological costs relating to higher pumping [CR] and also to higher assimilation costs.) The higher energy gain on T-Iso was mainly due to significantly higher CR on T-Iso (Table 3c, d). For the same reason, SFG upper thresholds for D. primolecta, i.e. food concentrations beyond which SFG fell below zero, were lower than those for T-Iso in both pearl oysters (Table 4). These results show the importance of energy-rich, ingestible and highly digestible food particles for the energy gain of pearl oysters and other suspension feeders.

The food particles, however, must not only provide the energy needs, but also the nutritional requirements of the pearl oyster. Okauchi (1990) found that, while T-Iso has higher energy and total nitrogen content than Isochrysis galbana and Chaetoceros gracilis, it was the poorest food species for supporting growth in Pinctada fucata martensii spat. The spat showed poorest growth when feeding on T-Iso compared to feeding on C. gracilis and I. galbana. Okauchi suggested that the low content in T-Iso of eicosapentaenoic acid (EPA), a potentially essential lipid, may be the dietary factor limiting its value for oyster growth (see also Pilsbury 1985, Helm \& Laing 1987). For culture of bivalves, T-Iso is generally used in combination with other microalgal species to achieve a diet without nutritional deficiencies. This is currently practised when using T-Iso as food for culturing bivalve larvae, including $P$. margaritifera and P. maxima larvae (e.g. Rose \& Baker 1994, Southgate \& Beer 1997).

Other studies have also demonstrated differences between microalgae species in their ability to support growth of pearl oyster larvae and spat, and differences between microalgae species in the rate at which they are filtered by pearl oysters. Wada (1973) demonstrated that Pinctada fucata martensii larvae feeding on pure diets of Pavlova lutheri and Chaetoceros calcitrans or on a mixture of these 2 algae $\left(1\right.$ to $2 \times 10^{4}$ cells $\mathrm{ml}^{-1}$ ) had higher growth rates than larvae feeding on a pure diet of Chlorella sp. or on mixed diets of Chlorella sp. with $P$. lutheri or C. Calcitrans. Nishimura (1980) assessed the influence of $P$. lutheri and Nitzschia closterium and ration $\left(20,50\right.$ and $100 \times 10^{3}$ cells $\mathrm{ml}^{-1}$ $\mathrm{d}^{-1}$ ) on growth of pearl oyster spat. Better growth rates were obtained with $P$. lutheri, especially at 20000 cells $\mathrm{ml}^{-1}$ during the first $20 \mathrm{~d}$, but there were no clear differences in growth at Day 28. Another study of $P$. fucata martensii demonstrated higher filtration rates (percentage of cells removed) when oysters were feeding on C. calcitrans $\left(72.6 \%\right.$ at ca 50000 cells $\left.\mathrm{ml}^{-1}\right)$, C. gracilis (69.1\%, at ca 20000 to 30000 cells $\mathrm{ml}^{-1}$ ) and $P$. lutheri (56.1 to $68.1 \%$, at ca 40000 cells $\mathrm{ml}^{-1}$ ) than when oysters were feeding on Chlorella sp. $(48.4 \%$, at ca 30000 cells $\mathrm{ml}^{-1}$ ) and Oithodiscus sp. (3.8\%, at ca 5000 cells ml-1) (Hayashi 1983)

\section{Broodstock conditioning}

Physiological energetics are a valuable tool for predicting long-term growth performance under specific environmental conditions (Beiras et al. 1994). Thus, the present study is relevant to a major aspect of pearl oyster farming, i.e. the maturation of broodstock in tanks using microalgal diets. Hayashi (1980) tested the broodstock maturation of Punctada fucata martensii in static indoor tanks using 2 different diets, homogenised rice starch powder and Pavlova lutheri, at 50000 to 60000 particles or cells $\mathrm{ml}^{-1} \mathrm{~d}^{-1}$. Hayashi reported better maturation of pearl oysters feeding on P. lutheri. However, fully mature individuals were not produced in this trial and the feasibility of artificial broodstock conditioning was not demonstrated.

There is no published study on broodstock conditioning of Pinctada margaritifera and P. maxima. However, our study suggests the potential for using optimum ration levels (i.e. 1 to $2 \mathrm{mg} \mathrm{l}^{-1}$ for $P$. margaritifera and 2 to $3 \mathrm{mg} \mathrm{l}^{-1}$ for $P$. maxima) of nutritionally rich microalgae, such as a 'balanced' diet containing T-Iso, for broodstock conditioning. If these rations are continuously fed to adult pearl oysters in an appropriate static or flow-through system, they should support gonadal development provided other conditions favour gametogenesis, e.g. temperature regime.

\section{Habitat differences}

Jørgensen $(1990,1996)$ concluded that the capacity for water processing in bivalves is an adaptation to the concentrations of suspended food that prevail in their biotope during the productive seasons of the year. Our studies on comparative feeding ecology of 2 species of tropical pearl oyster support this. Since Pinctada maxima processes more water than $P$. margaritifera when feeding in the high particulate range (Fig. 1), $P$. maxima should be better adapted to waters with higher particulate and productivity levels.

Both pearl oyster species occur in the Great Barrier Reef region (GBR), northeast coast of Australia (Hynd 1955, Dayton et al. 1989), but they occur in different habitats, as outlined in the 'Introduction'. Pinctada margaritifera tends to occur on coral reefs of fshore from the mainland, whereas P. maxima occurs on substrates ranging from mud to sand and gravel, but not on coral reefs. $P$. maxima tends to occur in the waters of the inner and middle shelf, where there are greater nutrient inputs and higher productivity levels than in coral reef 
habitats. The habitats of $P$. margaritifera are characterised by low levels of suspended particulate matter (SPM): SPM declines significantly from the inner to the outer continental shelf of the GBR (Oliver et al. 1995). Insofar as field data for SPM are available, and one can extrapolate these laboratory energetics data to the field (see below), the optimal food concentrations for P. margaritifera ( 1 to $2 \mathrm{mg} \mathrm{l}^{-1}$ ) are equivalent to SPM concentrations found in waters of the GBR continental shelf where coral. reefs occur (Oliver et al. 1995, Yukihira unpubl.). For example, the average annual SPM concentration was $1.47 \mathrm{mg} \mathrm{l}^{-1}$ (range: 1.18 to $1.72 \mathrm{mg} \mathrm{l}^{-1}$, $\mathrm{n}=21$; Yukihira unpubl.) near a fringing coral. reef in Pioneer Bay, Orpheus Island (18 $\left.37^{\prime} \mathrm{S}, 146^{\circ} 30^{\prime} \mathrm{E}\right)$, where $P$. margaritifera is common. The low food concentrations corresponding with the upper threshold of negative SFG of $P$. margaritifera (e.g. $5 \mathrm{mg} \mathrm{l}^{-1}$ for Dunaliella primolecta $\mathrm{l}^{-1}$ and $7 \mathrm{mg} \mathrm{l}^{-1}$ for $\mathrm{T}$-Iso) help to explain why this species is excluded from turbid water

SPM or equivalent data are not available for GBR habitats specifically inhabited by Pinctada maxima. How ever, its terrigenous sediment habitats in the inner to middle shelf region are characterised by turbid water and the SPM concentrations will fluctuate substantially due to river discharge and wind-driven re-suspension of sediment (Furnas et al. 1990, Furnas et al. 1995, Oliver et al. 1995). Reflecting this, at a near-shore site of the inner shelf at Cape Ferguson, the average annual SPM concentration was $12.22 \mathrm{mg} \mathrm{l}^{-1}$ (range: 1.95 to $60.37 \mathrm{mg} \mathrm{l}^{-1}$ i $\mathrm{n}=72$; Yukihira unpubl.). Although $P$. maxima has not been recorded from this site, it indicates the kind of conditions that this species may encounter at its most inshore distributions. Its higher optimum. SFG concentration (2 to $3 \mathrm{mg}^{-1}$ ) and upper threshold for negative SFG ( 7 or $9 \mathrm{mg} \mathrm{I}^{-1}$ ) are largely below these field SPM levels, but they are more in accord with these conditions than are the equivalent parameters for $P$ margaritifera. On the other hand, $P$. maxima may experience lower levels of SPM in its offshore, deepwater habitats. It is also well adapted to maintaining a positive SFG at low SPM levels (Table 4, Yukihira et al. 1998). Thus, $P$. maxima is better adapted than $P$. margaritifera to feeding over a broader range of SPM concentrations and this is reflected in its wider range of habitats.

Unlike the laboratory experiments of this study, where the SPM consisted of pure cultures of microalgae, SPM in the field is a mixture of microalgae species, non-living organic particles and inorganic particles. Much of the field SPM may have no nutritional value for the pearl oyster due to factors such as unmanageable size, indigestibility and no energy content. In considering bivalve feeding and energy budgets, there needs to be caution in extrapolating results from precise levels of SPM in laboratory studies to field situations. This has been recognised by other authors, e.g. Griffiths (1980), Riisgărd
(1991), and review by Jorgensen (1996). Thus, a further development of this study will deal with the feeding and energetics of Pinctada margaritifera and P. maxima supplied with natural suspended particles.

Acknowledgements. We thank Mr Michael Crimp of IndoPacific Pearl and Mr Bruce Stevens of Reefarm for providing some of the pearl oyster specimens. We are grateful to Dr Paul Southgate of JCU for constructive criticism of the manuscript. This study was supported in part by an Internal Research Allowance and a Meritorious Research Grant from JCU. H.Y gratefully acknowledges financial support from the Japan International Cooperation Agency. AIMS contribution number 927

\section{LITERATURE CITED}

Bayne BL, Brown DA, Burns $K$, Dixon DR, Ivanovici $A$, Livingstone DR, Lowe DM. Moore MN, Stebbing ARD, Widdows J (1985) The effects of stress and pollution on marine animals, Chap 1 (Physiological measurements) and 7 (Physiological procedures). Praeger Press, New York, p 4-45, 161-171.

Bayne BL, Hawkins AJS, Navarro E, Iglesias IP (1989) Effects of seston concentration. on feeding. digestion and growth in the mussel Mytilus edulis. Mar Ecol Prog Ser 55:47-54

Bayne BL. Newell RC (1983) Physiological energetics of marine molluscs. In: Wilbur KM et al. (ed) The Mollusca, Vol 4 , Physiology. Part 1. Academic Press, New York, p 407-515

Bayne BL, Scullard C (1977) An apparent scientific dynamic action in Mytilus edulis (L.). J Mar Bıol Assoc UK 57:371-378

Bayne BL, Worrall CM (1980) Growth and production of mussels, Mytilus edulis from two populations. Mar Ecol Prog Ser 3:317-328

Beiras R, Pérez-Camacho A, Albentosa M (1993) Influence of food concentration on energy balance and growth performance of Venerupis pullastra seed reared in an open-flow system. Aquaculture 116:353-365

Beiras R, Pérez-Camacho A, Albentosa M (1994) Comparison of the scope for growth with the growth performance of Ostrea edulis seed reared at different food concentrations in an open-flow system. Mar Biol 119:227-233

Cahalan JA, Siddall SE, Luckenback MW (1989) Effects of flow velocity, food concentration and particle flux on growth rates of juvenile bay scallops Argopecten irradians. J Exp Mar Biol Ecol 129:45-60

Conover RJ (1966) Assimilation of organic matter by zooplankton. Limnol Oceanogr 18:673-678

Dayton PK, Carleton JH, Mackley AG, Sammarco PW (1989) Patterns of settlement, survival and growth of oysters across the Great Barrier Reef. Mar Ecol Prog Ser 54:75-90

Doumenge F, Toulemont A, Branellec J (1991) The South Sea pearls: the Philippine golden pearl. Musée océanographique, Monaco, p 56

Dwivedy RC (1973) A study of chemo-receptors on labial palps of the American oyster using microelectrodes. Proc Natl Shellfish Assoc 63:20-26

Ewart JW, Eplfanio CE (1981) A tropical flagellate food for larval and juvenile oysters, Crassostrea virginica Gmelin. Aquaculture 22:297-300

Finlay BJ, Uhlig G (1981) Calorific and carbon values of marine and freshwater Protozoa. Helgol Meeresunters 34: 401-412

Foster-Smith RL (1975) The effect of concentration of suspension on the filtration rates and pseudofaecal production for 
Mytilus edulis L., Cerastoderma edule (L.) and Venerupis pullastra (Montagu). J Exp Mar Biol Ecol 17:1-22

Furnas M, Mitchell AW, Liston P, Skuza M, Wellington J (1990) Biological and chemical oceanographic measurements in the Far Northern Great Barrer Reef-February 1990. Great Barrier Reel Marine Park Authority Res Pub 34, Townsville, p 86

Furnas M, Mitchell AW, Skuza M (1995) Nitrogen and phosphorus budgets for the central Great Barrier Reef shelf Great Barrier Reef Marine Park Authority Res Pub 36, Townsville, p 194

Cervis MH, Sims NA (1992) The biology and culture of pearl oysters (Bivalvia: Pteriidae). ICLARM I Stud Rev 21

Griftiths RJ (1980) Filtration, respiration and assimilation in the black mussel Choromytilus meridionalis. Mar Ecol Prog Ser 3:63-70

Griftiths CL, Griffiths RJ (1987) Bivalvia. In: Pandian TJ, Vernberg FJ (eds) Animal energetics, Vol 2. Bivalvia through Reptilia. Academic Press, New York, p 1-87

Griffiths CL, King JA (1979) Some relationships between size, food availability and energy balance in the ribbed mussel Aulacomya ater. Mar Biol 51:141-149

Hawkins AJS, Smith RFM, Bayne BL. Héral M (1996) Novel observations underlying the fast growth of suspension feeding shellfish in turbid environments: Mytilus edulis L. Mar Ecol Prog Ser 131:179-190

Hayashi M (1980) Broodstock maturation trial for Japanese pearl oyster under indoor conditions. Mie Prefectural Fish. Res St Ann Rep Year 1978:73-75 (in Japanese)

Hayashi M (1983) Feeding rates of Japanese pearl oyster feeding on different diets. Mie Prefectural Fish Res St Ann Rep Year 1981:73-75 (in Japanese)

Helm MM (1977) Mixed algal feeding of Ostrea edulis larvae with Isochrysis galbana and Tetraselmis suecica. J Mar Biol Assoc UK 57:1019-1029

Helm MM, Laing I (1987) Preliminary observations on the nutritional value of 'Tahiti Isochrysis' to bivalve larvae. Aquaculture 62:281-288

Hildreth DI, Crisp DJ (1976) A corrected formula for calculation of filtration rate of bivalve molluscs in an experimental flowing system. J Mar Biol Assoc UK 56:111-120

Hynd JS (1955) A revision of Australian pearl shells, genus Pinctada. Aust J Mar Freshwat Res 6(1):98-137

Jorgensen CB (1990) Bivalve filter feeding: hydrodynamics, bioenergetics, physiology and ecology. Oisen \& Olsen, Fiedensborg

Jergensen CB (1996) Bivalve filter feeding revisited. Mar Ecol Prog Ser 142:287-302

Kailola PJ, Williams MJ, Stewart PC, Reichelt RE, MCNee A, Grieve C (1993) Australian fisheries resources. Bureau of Resource Sciences, Department of Primary Industries and Energy, and the Fisheries Research and Development Corporation, Canberra, p 87-89

Kirby-Smith WW, Barber RT (1974) Suspension-feeding aquaculture systems: effects of phytoplankton concentration and temperature on growth of the bay scallop. Aquaculture 3:135-145

Langdon CJ, Waldock M (1981) The effect of algal and artificial diets on the growth and fatty acid composition of Crassostrea gigas spat. J Mar Biol Assoc UK 61:431-448

Le Pennec M. Rangel DC (1985) Observations en microscopie a epifluorescence de l'ingestion et de la digestion d'algues unicellulaires chez des jeunes larves de Pecten maximus (Pectinidae, Bivalvia). Aquaculture 47:39-51

Navarro E, Iglesias JIP, Pérez-Camacho A, Labarta U (1996) The effect of diets of phytoplankton and suspended bottom material on feeding and absorption of raft mussels (Mytilus galloprovincialis Lmk). J Exp Mar Biol Ecol 198:175-189

Navarro E, Iglesias JIP, Pérez-Camacho A, Labarta U, Beiras R (1991) The physiological energetics of mussels (Mytilus galloprovincialis $\mathrm{Lmk}$ ) from different cultivation rafts in the Ria de Arosa (Galicia, N.W. Spain). Aquaculture 94:197-212

Navarro E, Iglesias JIP, Pérez-Camacho A, Labarta U, Beiras R (1992) Natural sediment as a food source for the cockle Cerastoderma edule (L.): effect of variable particle concentration of feeding, digestion and the scope for growth. J Exp Mar Biol Ecol 156:69-87

Navarro JM, Winter JE (1982) Ingestion rate, assimilation efficiency and energy balance in Mytilus chilensis in relation to body size and different algal concentrations. Mar Biol $67: 255-566$

Newell RIE, Jordan SJ (1983) Preferential ingestion of organic material by the American oyster, Crassostrea virginica. Mar Ecol Prog Ser 13:47-53

Nishimura A. (1980) Growth of Japanese pearl oyster and ration levels. Mie Prefectural Fish. Res St Ann Rep Year 1978:32-33 (in Japanese)

Okauchi M (1990) Food value of Isochrysis aff galbana for the growth of pearl oyster spat. Bull Jpn Soc Sci Fish 56(8): 1343

Oliver J, De'Ath G, Done I, Williams D, Furnas M, Moran P (eds) (1995). Long-term monitoring of the Great Barrier Reet, Status Report, no 1, 1995. Australian Institute of Marine Science, Townsville, p 121

Palmer RE (1980) Behavioral and rhythmic aspects of filtration in the bay scallop, Argopecten irradians concentricus (Say), and the oyster, Crassostrea varginica (Gmelin). J Exp Mar Biol Ecol 45:273-295

Palmer RE, Williams LG (1980) Effect of particle concentration on filtration efficiency of the bay scallop Argopecten irradians and the oyster Crassostrea virginica. Ophelia 19(2): $163-174$

Pillsbury KS (1985) The relative food value and biochemical composition of five phytoplankton diets for queen conch, Strombus gigas (Linne) larvae. J Exp Mar Biol Ecol 90: $221-231$

Riisgård HU (1991) Filtration rate and growth in the blue mussel, Mytilus edulis Linnaeus, 1758: dependence on algal concentration. J Shellfish Res 10(1):29-35

Rose RA, Baker SB (1994) Larval and spat culture of the Western Australian silver- or goldlip pearl oyster, $P$. maxima Jameson (Mollusca: Pteriidae). Aquaculture 126:35-50

Shirai S (1994) Pearls and pearl oysters of the world. Marine Planning, Okinawa, p 108

Solorzano L (1969) Determination of ammonia in natural waters by the phenol-hypochlorite method. Limnol Oceanogr 14: 199-801

Southgate P. Beer AC (1997) Hatchery and early nursery culture of the blacklip pearl oyster Pinctada margaritifera (L.). J Shellfush Res 16:561-568

Tenore KR, Dunstan WM (1973a) Companson of feeding and biodeposition of three bivalves at different food levels. Mar Biol 21:190-195

Tenore KR, Dunstan WM (1973b) Comparison of rates of feeding and biodeposition of the American oyster, Crassostrea virginica Gmelin, fed different species of phytoplankton. J Exp Mar Biol Ecol 12:19-26

Thompson RJ, Bayne BL (1972) Active metabolism associated with feeding in the mussel Mytilus edulis L. J Exp Mar Biol Ecol 9:111-124

Thompson RJ, Bayne BL (1974) Some relationships between growth, metabolism and food in the mussel Mytilus edulis. Mar Biol 27:317-326

Tranter DJ (1959) Reproduction in Australian pearl oysters 
(Lamellibranchia). IV. Pinctada margaritifera (L). Aust J Mar Freshwat Res 9(4):509-523

van Erkom Schurink C. Griffiths CL (1992) Physiological energetics of four South African mussel species in relation to body size, ration and temperature. Comp Biochem Physiol 101(4):779-789

Van Weel PB (1961) The comparative physiology of digestion in molluscs. Am Zool 1:245-252

Wada K (1973) Growth of Japanese pearl oy ster larvae fed with three species of microalgae. Bull Natl Pearl Res Lab 17:2075-2083 (in Japanese with English. summary)

Walne PR (1970) Studies on the food value of nineteen genera of algae to juvenile bivalves of the genera Ostrea, Crassostrea, Mercenaria and Mytilus. Fishery Invest Lond, Ser II, 26(5):1-62

Ward JE, MacDonald BA (1996) Pre-ingestive feeding behaviors of two sub-tropical bivalves (Pinctada imbricata and Arca zebra): responses to an acute increase in suspended

Editorial responsibility: Otto Kúnne (Editor),

Oldendorf/Luhe, Germany sediment concentration. Bull Mar Scl 59(2):417-432

Warren CE, Davis GE (1967) Laboratory studies on the feeding, bioenergetics, and growth of fish. In: Gerking SD (ed) The biological basis of freshwater fish production. Blackwell Scientific Publications, Oxford, p 175-214

Whyte JNC (1987) Biochemical composition and energy content of six species of phytoplankton used in mariculture of bivalves. Aquaculture 60:231-241

Widdows J, Fieth P, Worral CM (1979) Relationships between seston, available food and feeding activity in the common mussel Mytilus edulis. Mar Biol 50:195-207

Winter JE (1978) A review on the knowledge of suspensionfeeding in Lamellibranchiate bivalves, with special reference to artificial aquaculture systems. Aquaculture 13:1-33

Yukihira $H_{1}$ Klumpp DW, Lucas JS (1998) Effects of body size on suspension feeding and energy budgets of the pearl oysters Pinctada margaritifera and P. maxima. Mar Ecol Prog Ser 170:119-130

Submitted: Aprl 15, 1998; Accepted: July 7, 1998 Proofs received from author(s): September 16, 1998 